Najiba BAGIRZADEH, orcid.org/0000-0002-5359-1794 Doctoral Student National Museum of Azerbaijan Literature named after Nizami Ganjavi of National Academy of Sciences of Azerbaijan (Baku, Azerbaijan) rus_rahimli@yahoo.com

\title{
MOHAMMAD AMIN RASULZADEH'S RESEARCHES ON AZERBAIJANI LITERATURE
}

The literary researches of Mohammad Amin Rasulzadeh, who started the war of national independence from his early youth, are also very interesting. His literary research dates back to the period of emigration after the collapse of the Republic. Until then, MA Rasulzadeh himself had written several plays, but more as a publicist he published articles in the press. In exile, MA Rasulzadeh closely followed Azerbaijani literature, wrote about the life and work of all writers and poets who were the bearers of national ideology persecuted after the occupation of Bolshevik Russia, and managed to create a broad picture of the literary environment in Soviet Azerbaijan. MA Rasulzadeh followed and analyzed the works of such poets and writers as H. Javid, A. Javad, A. Yildirim, J. Jabbarli, U. Sadiqzade, AAGultekin. Each of these studies can be considered an invaluable source in the study and correct evaluation of Soviet literature. MA Rasulzadeh connected the national awakening of the Azerbaijani people, development and prosperity of literature in the early twentieth century, first of all, with the political and social events in Russia, Iran and Turkey in the three countries, and noted that literature gave impetus to these events through propaganda. Two literary schools established in Azerbaijan at the beginning of the 20th century; We all know today how the romantic and realist literary schools played a great role in the development of our literature, press and culture. Representatives of both literary schools caused innovations in our literature by innovating both form and content. Thus, a high development took place in Azerbaijani literature. Of course, this development was also a great help to MA Rasulzadeh, a representative of the romantic literary school. The article is devoted to the study of this role and its analysis in the political context, revealing points that did not exist in the previous literature. Theoretical and methodological basis of the research is a historical-comparative and descriptive method.

Key words: Mohammad Amin Rasulzade, Azerbaijani literature, Soviet regime, Republican ideology, love of independence, longing for homeland.

\author{
Наджіб БАГІРЗАДЕ, \\ orcid.org/0000-0002-5359-1794 \\ докторант \\ Національного музею азербайджанської літератури імені Нізамі Гянджеві \\ Національної академії наук Азербайджану \\ (Баку, Азербайджан) rus_rahimli@yahoo.com
}

\section{ДОСЛІДЖЕННЯ МОХАММАДА АМІНА РАСУЛЗАДЕ ПРО АЗЕРБАЙДЖАНСЬКУ ЛІТЕРАТУРУ}

\footnotetext{
Цікаві літературні дослідження Мохаммада Аміна Расулзаде, який із ранньої юності розв'язав війну за національну незалежність. Його літературні дослідження сягають періоду еміграџії після розпаду республіки. На той час сам М. А. Расулзаде написав кілька п’єс, але більше як публічист публікував статті в пресі. У вигнанні М.А. Расулзаде уважно стежив за азербайджанської літературою, писав про життя $і$ творчість усіх письменників і поетів, які були носіями наџіональної ідеологїі, переслідуваної після окупацї більшовицькою Росії, $i$ зумів створити широку картину літературної $і$ літературного середовища в Росії. М.А. Расулзаде стежив $i$ аналізував творчість таких поетів і письменників, як Х. Джавід, А. Джавад, А. Йилдирим, Дж. Джаббарли, У. Садікзаде, А. А. Гультекін. Кожне з ичих досліджень можна вважати безцінним джерелом під час вивчення $i$ правильної оцінки радянської літератури. М. А. Расулзаде пов'язав національне пробудження азербайджанського народу, розвиток і проивітання літератури на початку XX століття з політичними і суспільними подіями 6 Росії, Ірані та Туреччині і зазначив, щьо література дала поштовх розвитку иих подій за допомогою пропаганди. На початку 20 століття в Азербайджані засновано дві літературні иколи, відомі сьогодні як романтична $i$ реалістична. Вони зіграли значну роль у розвитку нашої літератури, преси та культури. Представники обох літературних шкіл вносили нововведення в нашу літературу, оновлюючи як форму, так $i$ зміст. Таким чином, азербайджанська література отримала великий розвиток, щчо допомогло $i$ представникові романтичної літературної школи М. А. Расулзаде. Стаття присвячена вивченню ичієї ролі та ї̈ аналізу в політичному
} 
контексті, виявляючи моменти, яких не було в попередній літературі. Теоретичною і методологічною основою дослідження є історико-порівняльно-описовий метод.

Ключові слова: Мохаммад Амін Расулзаде, азербайджанська література, радянський режим, республіканська ідеологія, незалежність, туга за Батьківщиною.

Introduction. The actuality of the subject. The role of literature in the formation of national thinking and the development of the national language is irreplaceable. It plays an important role in the survival, enrichment and transmission of the national language to the future. Because national literature contains the history, political and cultural heritage of the nation. As you look through the literature of each nation, it is possible to understand what historical periods it went through. To confirm this opinion, it is enough to look at the Azerbaijani literature of the XX century. The political defeat in Azerbaijan, which was enslaved by Russia under the Bolshevik occupation, manifested itself in the literary sphere as well, and the Soviet ideology influenced all literature. This period, like Soviet literature, entered the history of Azerbaijani literature.

Purpose and tasks of the research. The main purpose of the research is to investigate the researches of Rasulzadeh on Azerbaijani literature. The article is dedicated to the study and promotion of the life and career of MA Rasulzade, who played a prominent role in the socio-political, literary and cultural environment of Azerbaijan and left a unique creative legacy.

Scientific novelty of research. The research work has enabled us to achieve objective scientific and theoretical results in the research of Rasulzadeh's literary legacy. The role of the literature that Muhammad Amin Bey followed and propagated would be significant in the coming of that day.

Methods and sources of research. Theoretical and methodological basis of the research is a historical-comparative and descriptive method. The subject of the research is Azerbaijan's literature and archives, legacy of Rasulzadeh.

A review of recent research and publications. Rasulzade's literary heritage, literary research, and literary considerations in a political context have been studied by several authors. Some of them are: Ahmed Javad. ("The voice of truth"), Sultanli V. ("Love of Independence "), Yagublu Nasiman. ("The founders of the republic"), ("Mammad Amin Rasulzadeh: political portrait"), Aydın Balayev ("Mammad Amin Rasulzade. Homeland dispute abroad. 1922-1943"), Vagif Sultanli ("Literary World of Muhammad Amin Rasulzadeh"), Alkhan Bayramoglu ("Literature in the Period of the Democratic Republic of Azerbaijan"), Shamil Gurbanov ("Mammad Amin Rasulzadeh"), Nasiman Yagublu ("Mammad Amin Rasulzadeh"),
Badirhan Ahmedov ("History of Azerbaijani Literature of the 20th Century"), Aybeniz Aliyeva-Kangarli ("Literature Issues in the Azerbaijan Newspaper 1918-1920"), Ramiz Gasimov and Zulfiyya Ismayil ("The Concept of National Ideology in Azerbaijani Literature and Ideology of Azerbaijanism"), H. Baykara ("The History of the Independence Struggle of Azerbaijan) and other authors.

Presentation of the main material. Along with his political activity, Mohammad Amin Rasulzadeh, who followed the literary processes in the country from the beginning of his literary career and wrote poems, plays such as "Lights in the Dark" and "Sudden Disaster", had to continue his research on Azerbaijani literature in exile after the collapse of the Republic. "Along with the political struggle, MA Rasulzadeh, who always paid attention to literary criticism, began to create significant works on the classics of Azerbaijani literature and its scientific and theoretical problems in the thirties. The published books show that from those years until the end of his life, MA Rasulzade's work was connected with literary criticism in terms of his interest (Sultanli, 2014: 81-82).

Each of these works is a reliable source that provides the reader with complete and accurate information about Azerbaijani literature. Mohammad Amin also fought for Azerbaijan in exile, followed all the processes taking place in the homeland, wrote his views on Azerbaijani literature, and tried to promote this literature by publishing these works. MA Rasulzadeh's works in the field of literary criticism are also interesting and valuable due to his accurate assessment of Azerbaijani literature, works of writers and poets, the period of their creation. These studies are very different from the researches of Soviet literary critics, who tried to destroy and forget the ideology of the republic and became the mouthpiece of communist ideology. Despite the false pathos of Soviet literary critics engaged in the study and promotion of proletarian literature in Soviet Azerbaijan, Rasulzade wrote bitter truths: "In 1937, as in all Soviet countries, there were violent purges in Azerbaijan. During these years, the so-called period of genocide, the cultural forces in Azerbaijan were substantially eliminated. There was no doubt that national poets such as Huseyn Javid and Ahmad Javad would be destroyed during these bloody years when local communists, who played an important role in the consolidation of Azerbaijan, were strangled (Rasulzadeh, 1990a: 73-74). 
The Soviet regime suppressed the republican ideology in one way or another by suppressing the words of national-minded poets and writers who were full of love for independence. They lost their lives in captivity and exile, and their works were banned. Another way was found to keep the new generation unaware of these values, as Rasuzlada wrote in this regard: "In 1939, the mold of this cultural policy applied to the Turkic peoples was found. Turkish scripts, which were once converted from the Arabic alphabet to the Latin alphabet, were converted to the Russian alphabet, called Cyrillic. From that day on, the ideology was pursued during the so-called "Soviet ideal" of "unification with the great Russian nation."

Starting from this period, there is not Azeri or Azerbaijani Turkish, but Azerbaijani language, nation and literature (Rasulzdeh, 1990b: 74). The Soviet regime used this tool to separate the Turkic world, the Turkic nations living in the Soviet Union, and to forget their national identity, and for 70 years it has achieved this to some extent. This issue made Rasulzade think. Because he was also concerned about the fate of artists who were propagandists of communist ideology, based on national values at the time of the emergence of literature that mangled nations, and included the entire Turkic world in their work.

Rasulzadeh writes in his book "Contemporary Azerbaijani Literature" about the works of Huseyn Javid, who died in the frosty, cold plains of Siberia and valued his personality and art. Speaking about "Iblis", H. Javid emphasizes that it is important that national feelings are in the thoughts and ideas. Of course, these thoughts could still be conveyed to readers through literature. "In this work, written with the strongest revolutionary zeal, the genius poet pays special attention to the main idea that does not leave him - the idea of nationality and Turkism. In the words of one of the heroes, he said that a sword alone was not enough to save Turan:

Turanda q1lıncdan daha kəskin ulu qüvvət,

Yalnız mədəniyyət, mədəniyyət, mədəniyyət!..

A greater force in Turan than the sword,

Just culture, culture, culture" (Rasulzadeh, 1990c: 67).

He writes that the young people who came to literature appealed to Mr. Javid as a great master and needed his blessing, which shows the authority of H. Javid in the literary environment and Rasulzade's sympathy for him.

One of the poets included in Rasulzade's work "Contemporary Azerbaijani Literature" is Ahmad Javad, one of our poets who lived with the love of independence. The freedom, independence and high flag of the nation are the spirit and breath of this poetry.
"Köksümdə tufanlar gəldim irəli, Öpdüm kölgən düşən mübarək yeri.

Allahın yıldızı, o gözəl pəri,

Sığınmış qoynunda aya, bayrağım!"

"Storms came in my heart,

Blessed is the place where I kissed the shadow.

The star of God, that beautiful fairy,

My flag has embraced the moon!"

(Javad, 1991: 10) - The poetry of the poet who wrote these verses is incomparably magnificent and irreplaceable at this point. These examples of poetry, full of national feelings, are a great gift of A. Javad to Azerbaijani literature.

"Articles against A. Javad were published in the Soviet press from time to time. He was severely criticized. Soviet critics wrote: "Let's talk a little about old poets. We do not think that poets like Javad Akhundov and Huseyn Javid will make a necessary turn in the near future ... In terms of content, the writings of these poets are against the new society and the new Azerbaijani culture (Yagublu, 2018: 652). MA Rasulzadeh, a great politician and literary critic who fought for Azerbaijan in exile, wrote in his book "Contemporary Azerbaijani Literature": He is arrested because he is an old "Musavat member". He is removed and expelled from the press and literary congresses. They do not publish their works and collect the published ones." (Rasulzadeh, 1990d: 68).

One of the owners of the national spirit was Jafar Jabbarli, who in his work "Contemporary Azerbaijani Literature" Mohammad Amin spoke about his life and work. Unlike Soviet literary critics, Rasulzade presents Jabbarli's works in a different interpretation. MA Rasulzadeh describes what happened in "Bride of Fire" as follows: After a terrible struggle, he is captured and sentenced to death. He is forced to recite the testimony under a narrow tree with his hands tied behind his back. He shouts, "Even if the whole world says, I will not say la ilaha illallah."

The symbolism of the situation is obvious. For the audience, replacing the words "Arabic" and "Islam" with the words "Russian" and "communism" is enough to actualize the meaning." (Rasulzadeh, 1990e: 71). Rasulzade's interpretation is interesting and thought-provoking. It is difficult to say whether Jabbarli really meant the Arabs or the Russians who invaded Azerbaijan. But in any case, the occupation of Azerbaijan is unacceptable, and we think that Rasulzade's analysis of the work "Bride of Fire" was due to the desire to draw attention to this point. Mohammad Amin, who regretted Jabbarli's death at a young age, did not even reconcile with the fact that the Azerbaijani commissars sent him to death.

Umgulsum Sadigzadeh (Rasulzadeh) was one of the poets who was physically destroyed due to her 
hatred of the Bolshevik invasion and her love for our independence, and Muhammad Amin followed and appreciated her work from the very beginning.

By the way, it should be noted that the talented literary critic Rasim Tagiyev first introduced readers to the life and work of Ummugulsum in 1971 in the pages of the magazine "Azerbaijani woman", gave brief information about her (Ummugulsum, 1992: 4). Umgulsum Sadigzadeh is the only female poet in exile in the Soviet Union at that time. In his book "Contemporary Azerbaijani Literature" written in exile, Rasulzadeh does not mention this lady, who is not silent in the face of injustice, rebellious poetry and emotional lyrics, but conveys to the reader the poem "Hijran" by the poet who protested against the Soviet regime that destroyed all Rasulzadeh's lives. There is probably a meaning in Rasulzadeh's mention of this poem by his cousin Umgulsum khanum. Rasulzadeh's longing for his homeland, separated from his relatives and loved ones, as well as the light of hope, along with the suffering of thousands of his compatriots, are reflected here.

Rasulzadeh talks about poets such as Sanan and Yayjili Karim in his book "Contemporary Azerbaijani Literature" and gives examples from his poems. Almas Yildirim, who suddenly flashed like lightning in Azerbaijani poetry, but whose light and sound lasted forever, is also one of our poets included in Rasulzade's research. MA Rasulzadeh, who gave great value to this strange, patriotic poet, wrote about him: "Almas Yildirim, who was thrown into the arena of life in explosive days and fled the Soviet occupation and is now in exile, expresses his feelings of patriotism in his poem "Abroad" (Rasulzadeh, 1990f: 84).

Despite the fact that the Soviet regime physically destroyed poets like him, the role of Mohammad Amin in the transmission of his poetry to the present day, in the disclosure of its essence and literary burden should also be noted. There is a noteworthy point in Rasulzade's research on Azerbaijani literature, which is the attitude of the writers to the independence of the country and the way he struggled with his pen. Mohammad Amin appreciates those poets and writers, whose work has played a role in the survival of national thinking, the love of independence, and its transmission to the future.

"In this spirit and in this belief, many young forces are being destroyed in various Soviet prisons. Poet Gultekin gave a beautiful poem dedicated to these oppressed Azerbaijani brothers entitled "Ice Hell" (Rasulzadeh, 1990g: 84). Unfortunately, Muhammad Amin's own family members were among those sentenced to a thousand and one hardships of exile in the cold steppes of Siberia, and such poems seemed to be a expression of his heartache. On the other hand, he knew every Azerbaijani oppressed in his/her homeland under the persecution of Bolshevik Russia as his own, and considered the tragedy of each of them as his own tragedy.

M. A. Rasulzadeh completes "Contemporary Azerbaijani Literature" with the famous verses of Amin Abid Gultekin. "You are ours, you are ours, as long as you stand, live in the body, Long live, long live, long live, glorious Azerbaijan!" (Rasulzadeh, 1990h: 86). These verses are the expression not only of Amin Abid Gultekin, but also of Rasulzadeh and his colleagues like him, who spent their lives abroad, and the eternal love of our people for our independence. It is no coincidence that Mohammad Amin Bey completed his speech on Radio "Liberty" in 1953 with these verses. These verses, which we can hear in his memorable voice, which is native to the whole nation, sound like the anthem of love for Azerbaijan, the nation, independence, which lives in the hearts of millions of people. Amin Abid is a happy artist, and Mohammad Amin Rasulzadeh conveyed this love to millions through his poems.

The result. Rasulzadeh followed all the literary and cultural processes in Azerbaijan after the Bolshevik invasion and gave them a real value. Because even though it was politically occupied, he wanted to see Azerbaijan among the culturally developed countries. Mohammad Amin Rasulzadeh wrote about these successes that he followed from afar: "Among the abundance of propaganda material in the field of national literature and theater, there are also valuable works that are a positive asset of Azerbaijani culture. The repertoire of the Azerbaijani stage has been enriched. Almost all classical plays of European nations have been translated into Azerbaijani. Many materials on the past of Azerbaijani literature and history have been published. A lot of material on folklore has been collected and published. A new edition of the classics of Azerbaijani literature has been published.

Although the communist spirit was naturally infused in all Soviet journalism and propaganda literature, the content of scientific and literary literature was not so much exposed to communist poison (Rasulzadeh, 2009: 55).

It was as if these gave moral strength to Rasulzadeh, who lived abroad longing for his homeland and longed for the independence of Azerbaijan. It was a consolation, at least in part, for him to see the Republican ideology and national language in his country. The needle-sized lights were a sign of the cinder under the ashes would re-ignite. Of course, the role of the literature that Muhammad Amin Rasulzadeh followed and propagated would be significant in the coming of that day. 


\section{BIBLIOGRAPHY}

1. Javad A. The voice of truth. Azerbaijan Union of Journalists. "Nijat" Publishing House Baku, 1991

2. Rasulzadeh M.A. Sayavush of Our Century, Contemporary Azerbaijani Literature, History of Contemporary Azerbaijan. B., Youth, 1990. 112 p.

3. Rasulzadeh M.A. National movement in Azerbaijan. Baku: "Science", 2009,128 p.

4. Sultanli V. Love of Independence. Baku, Science and education, 2014, 252 p.

5. Ummugulsum. Our eyes are teary, our hearts are wounded. Azerbaijan Union of Journalists "Nijat" publishing house Baku, 1992.

6. Yagublu N. The founders of the republic. Baku, "Nurlar" Publishing and Printing Center, 2018, 504 p.

7. Yildirim A. Black saga. Poems. -Baku, “Azerbaijan” publishing house, 1994, 144.p.

\section{REFERENCES}

1. Javad A. The voice of truth. Azerbaijan Union of Journalists - "Nijat" Publishing House Baku, 1991

2. Rasulzadeh M.A. Sayavush of Our Century, Contemporary Azerbaijani Literature, History of Contemporary Azerbaijan. B., Youth, 1990. 112 p.

3. Rasulzadeh M.A. National movement in Azerbaijan. Baku: "Science", 2009,128 p.

4. Sultanli V. Love of Independence. Baku, Science and education, 2014, 252 p.

5. Ummugulsum. Our eyes are teary, our hearts are wounded. Azerbaijan Union of Journalists "Nijat" publishing house Baku, 1992.

6. Yagublu N. The founders of the republic. Baku, "Nurlar" Publishing and Printing Center, 2018, 504 p.

7. Yildirim A. Black saga. Poems. -Baku, “Azerbaijan” publishing house, 1994, 144.p. 